\title{
Long-Term Impacts of \\ Anthropogenic Forcing
on the
Black Sea Ecosystem
}

BY TEMEL OGUZ

$\mathrm{T}$

he Black Sea, a nearly enclosed and isolated environment, has suffered from severe ecological changes during the last three decades. It has been converted from an oligotrophic (less than 100 grams of organic carbon per meters squared per year $\left.\left[\mathrm{g} \mathrm{C} / \mathrm{m}^{2} / \mathrm{yr}\right]\right)$ system prior to the 1970s (the pre-eutrophication phase) to a eutrophic (300 to 500 $\mathrm{g} \mathrm{C} / \mathrm{m}^{2} / \mathrm{yr}$ ) system over the subsequent two decades (the eutrophication phase). The Black Sea has been called the largest eutrophic, or even hypertrophic (greater than $500 \mathrm{~g} \mathrm{C} / \mathrm{m}^{2} / \mathrm{yr}$ ), water body in the world (Arai, 2001), even though there is a great deal of spatial heterogeneity over the basin. Several factors may play a role in these changes: excessive nutrient and pollutant input (Mee, 1992; Zaitsev and Mamaev, 1997), outbursts of the alien ctenophore species Mnemiopsis leidyi (Shiganova, 1998; Kideys and Romanova, 2001; Kideys, 2002; Kideys et al., this issue), overfishing (Prodanov et al., 1997; Daskalov, 2002; Gucu, 2002), and cli- mate impacts on the physical structure (Daskalov, 2003; Oguz, this issue). Bilio and Niermann (2004) provided a comprehensive assessment of various factors responsible for the ecosystem transformations. A general implication of all these studies is that the complexity of ecological changes result from the concomitant roles of anthropogenic inputs and climatic forcing. Identification of possible future changes and mitigation of the negative impacts of the deterioration require understanding the relative influence of these individual contributions.

The two-part series of papers in this issue by the author makes use of the 40year-long (1960 to 2000) published data on physical and biochemical properties of the Black Sea, and provides a descriptive model for the way in which the Black Sea ecosystem has been perturbed and restructured since the 1960s. The first part (this paper) specifically considers the bottom-up control by excessive nutrient loading from rivers, and the top-down control by pelagic fishes and gelatinous carnivores. The second paper focuses on the role of climate-induced variations.

\section{IMPACTS OF EUTROPHICATION}

Since the late 1960s, the Black Sea has been subject to nutrient enrichment due to the discharge of excessive domestic and agricultural waste from rivers into the northwestern continental shelf (NWS). The Danube River constituted nearly 75 percent of the total input (Zaitsev and Mamaev, 1997). Excess nutrients have accumulated within the upper $\sim 100$ $\mathrm{m}$ above the pycnocline due to very limited water exchange laterally through the Bosporus Strait and vertically across the permanent pycnocline. Within a decade, the Black Sea, which was poorly productive prior to the late 1960 s, became susceptible to severe eutrophication (defined as "the process of changing the nutritional status of a given water body by increasing the nutrient resources") (Richardson 


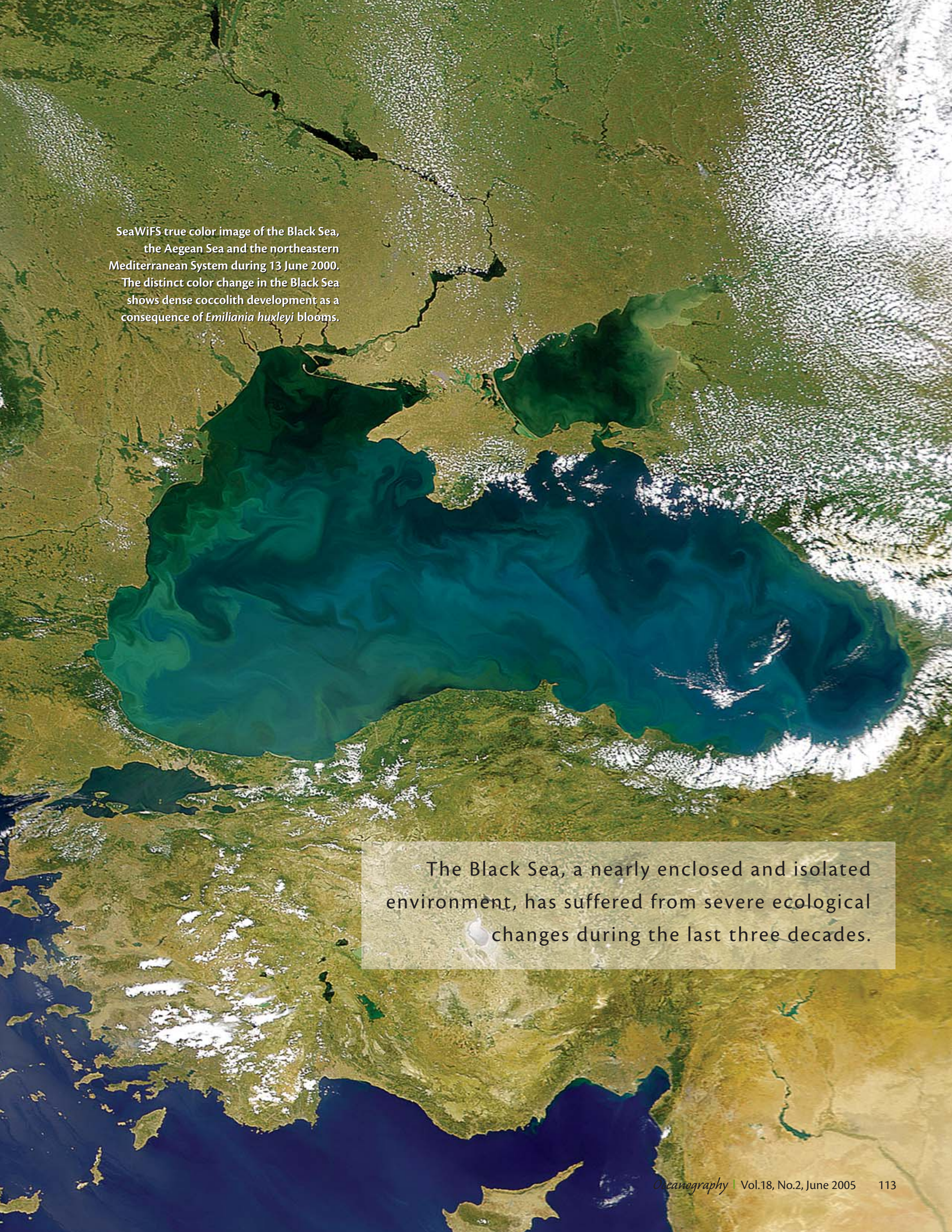


and Jorgensen, 1996). This section provides a brief overview of the changes in the Black Sea's nutrient structure, and its impact on the lower trophic food web and the vertical biogeochemical pump.

\section{Changes in the Nutrient Structure}

Continuous measurements taken in close proximity to the Danube delta have documented an order of magnitude increase in the surface phosphate concentration from 1 to $2 \mu \mathrm{M}$ in the 1960 s to 10 to 20 $\mu \mathrm{M}$ in the 1970s and 1980s (Popa, 1995; Humborg et al., 1997). Considerable changes in nutrient stocks within the Romanian inner shelf have been monitored by the monthly measurements from 1963 to 1995 at a 40-m deep-station located 20 nautical miles offshore Constantza. Phosphate and silicate concentrations, averaged over the water column and over the year (Figure 1), have varied profoundly from 0.2 to $1.5 \mu \mathrm{M}$ and from 30 to $60 \mu \mathrm{M}$, respectively, between 1968 and 1974. By the second half of the 1970s, a decrease in river discharge after construction of dams along the Danube and a reduction in the agricultural use of phosphate resulted in a strong reduction in both phosphate and silicate concentrations until 1982. These concentrations were then maintained more or less at a steady level of about 5 to $10 \mu \mathrm{M}$ for silicate and 0.2 to $0.3 \mu \mathrm{M}$ for phosphate. Nitrate concentrations, measured routinely only since the beginning of the 1980 s at this particular station, also showed a similar decreasing trend from values around $15 \mu \mathrm{M}$ during the first half of the 1980 s, to 7 to $8 \mu \mathrm{M}$ during its second half, to around 4 to $5 \mu \mathrm{M}$ during the early 1990s. Nutrient concentrations were

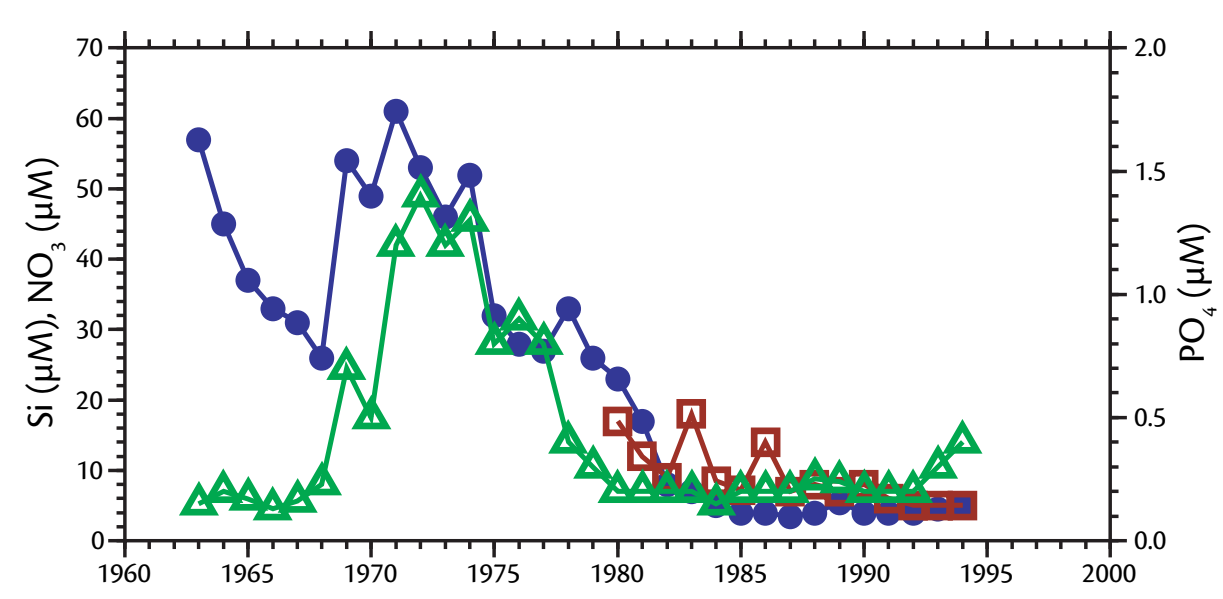

Figure 1. Temporal distributions of silicate (dots), phosphate (triangles), and nitrate (squares) concentrations $(\mu \mathrm{M})$ at $44^{\circ} 10^{\prime} \mathrm{N}, 29^{\circ} 09^{\prime} \mathrm{E}, 20$ nautical miles offshore Constantza (northwestern shelf of the Romanian coast). The original data (Cociasu et al., 1996), based on the monthly measurements over the 40-m-deep water column, were converted to the annual and depth-averaged form for the present study. The sharp drop in silicate and phosphate concentrations from 1974 to 1975 coincides with the damming of the Danube at Iron Gates. The relatively high nutrient concentrations of the shelf areas are shown to level off after the mid-1980s. reported to remain steady at this reduced level during the rest of the 1990s within the Romanian inner shelf waters (Cociasu and Popa, 2002). As shown in the second of these articles (Oguz, this issue), eutrophication weakening, together with the prevailing climatic warming, profoundly altered the biogeochemical structure of the Black Sea during the 1990s. According to the data shown in Figure 1, inner shelf waters of the northwestern Black Sea may have been under co-limitation by silicate, phosphate, and nitrogen depending on local conditions. The silicate to nitrogen (Si:N) ratio decreased from values of more than 4 , to 1 to 2 , during the 1980 s and 1990s. The nitrogen to phosphate $(\mathrm{N}: \mathrm{P})$ ratio varied between 10 and 20 .

The excessive anthropogenic-based nutrient supply has also been traced within the deep interior basin further away from its source region. By comparing data from the R/V Atlantis 1969, R/V Knorr 1988, and R/V Bilim 1991 surveys within the western central basin, Tugrul et al. (1992) was the first to note an upward shift in the position of the subsurface nitrate maximum by about $10 \mathrm{~m}$ and increase in its concentrations from $\sim 2$ to $3 \mu \mathrm{M}$ to 7 to $9 \mu \mathrm{M}$ (see Figure 2 in Oguz et al., 2000). The interior basin responded to the gradual reduction in anthropogenic nitrate supply into the NWS that occurred after the mid-1980s by showing a reduction in its nitrate peak concentrations from greater than $6 \mu \mathrm{M}$ to around $5 \mu \mathrm{M}$ during the 1990s (see Figure 8a in Konovalov and

Temel Oguz (oguz@ims.metu.edu.tr) is Professor, Institute of Marine Sciences, Middle East Technical University, Mersin, Turkey. 
Murray, 2001). Available nutrient data indicated strong nitrogen limitation in the euphotic zone waters of the interior basin with N:P ratios of 4 to 6 and Si: $\mathrm{N}$ ratios of 6 to 10 during the 1980s and the early 1990s (Basturk et al., 1997). The data collected after 1995 on the R/V Bilim within the western and eastern gyres (Figure 2) also supported strong nitrogen limitation, as the N:P ratio was typically less than 8 and the Si:N ratio was greater than 6 .

\section{Changes in the Lower Trophic Food Web Structure}

Excessive anthropogenic nutrient supply considerably altered the lower trophic food web structure during the 1980s. The succession, intensity, frequency, and extension of phytoplankton (microscopic plants) blooms have been modified all over the basin. For example, along the western coastal waters, the percentage of dinoflagellates (a microscopic algae found in excess in many harmful algal blooms) in these blooms increased from $\sim 15$ percent prior to 1970 to $\sim 60$ percent during the 1980s and 1990s, while the percentage of diatoms (another microscopic algae) decreased (Bodeanu, 1993; Moncheva and Krastev, 1997). After 1970, summer blooms occurred regularly in addition to the regular spring blooms. These blooms had mixotrophic character, involving dinoflagellates, coccolithophores (a type of phytoplankton with calcite shells which give blue-green color to water during their blooms), and euglenophytes (a primitive type of protist) (Bodeanu, 1993; Moncheva and Krastev, 1997).

As shown in Figure 3, the summer-autumn (May-to-November) mean phyto-
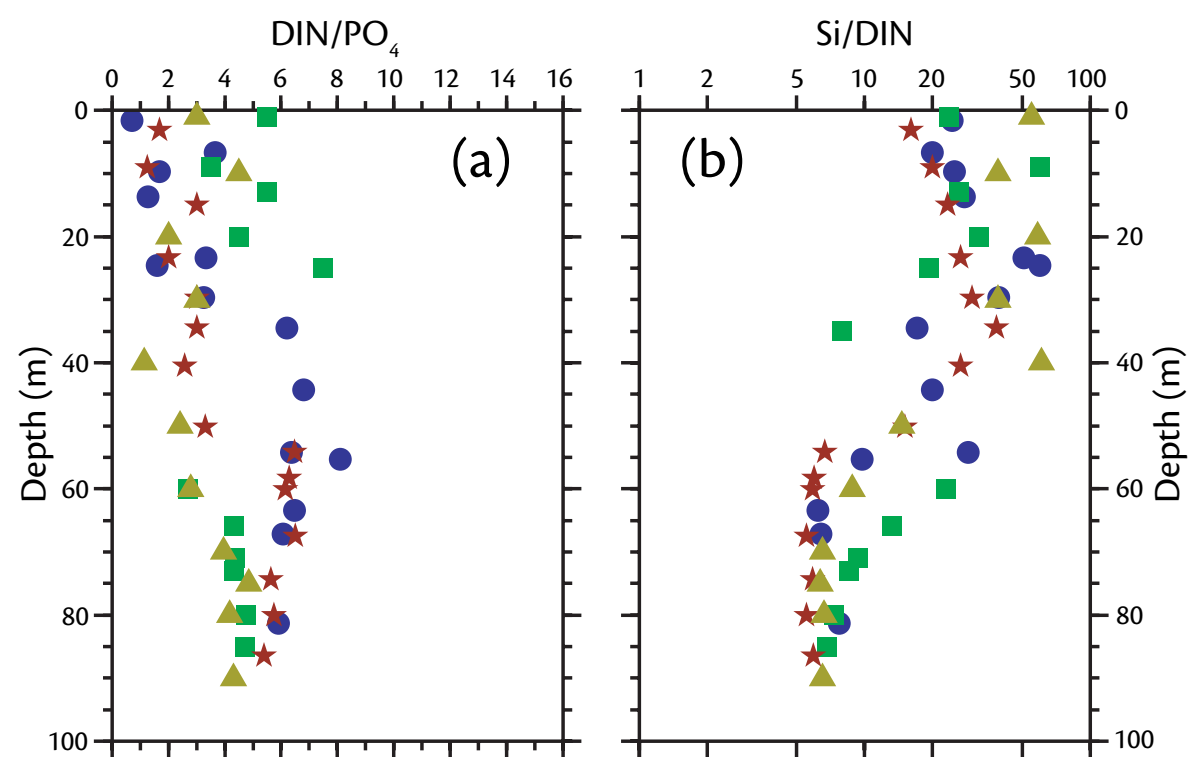

Figure 2. Vertical profiles of (a) dissolved inorganic nitrate to phosphate (DIN/PO $)$, and (b) silicate to nitrate (Si/DIN) at $42^{\circ} 15^{\prime} \mathrm{N} 29^{\circ} 15^{\prime} \mathrm{E}$ (triangles) during 18 March 1995

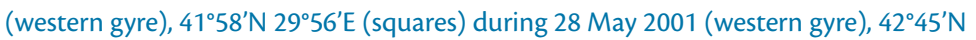
$36^{\circ} 45^{\prime} \mathrm{E}$ (dots) during 3 October 1999 (central basin), 42 $30^{\circ} \mathrm{N} 37^{\circ} 45^{\prime} \mathrm{E}$ (stars) during 22 April 1998 (eastern gyre). The profiles are chosen from the R/V Bilim measurements archived in the METU-Institute of Marine Sciences (Turkey) database. The data, which have been collected within different parts of the interior basin during the post-eutrophication phase of the ecosystem, suggest persistence of strong nitrogen limitation as in the previous decades with DIN/PO ${ }_{4}$ ratio typically less than 8 and Si/DIN ratio typically greater than 6 .

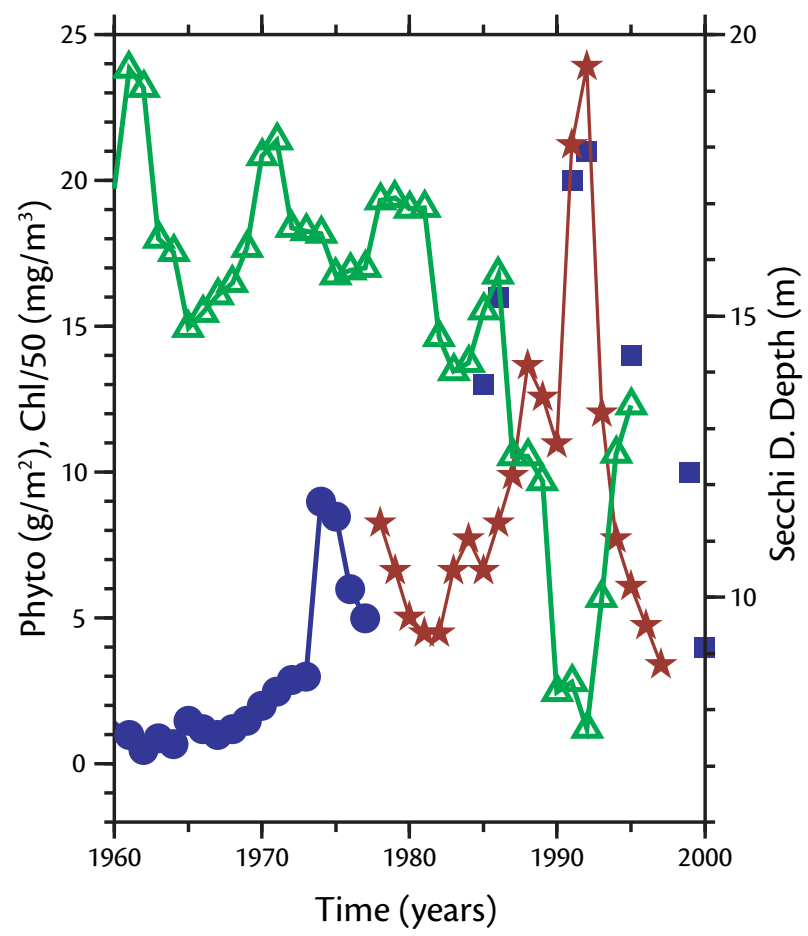

Figure 3. Temporal variations of the surface phytoplankton biomass (circles and squares), chlorophyll concentration (stars), and the Secchi depth (triangles). Phytoplankton data are given by Mikaelyan (1997), chlorophyll data by Vedernikov and Demidov (2002), and the Secchi data by Mankovski et al. (1998) as the averages of all measurements within the interior basin for the summer to autumn period for the former two data sets, and the average of measurements within each year for the latter data set. Both phytoplankton biomass and chlorophyll concentration data possess pronounced increases associated with the eutrophication during the 1980s, which are also supported by accompanying decrease in the Secchi depth data. 
Figure 4. Temporal variations of mesozooplankton biomass: circles denote the annual-mean of all measurements within the interior basin (Kovalev et al., 1998; Kideys et al., 2000), and bars represent the data from the northeastern sector of the Black Sea (Shiganova et al., 2003). The combination of eutrophication-induced botcontrols by gelatinous carnivores and small pelagic fishes lead to strong variations in the mesozooplankton biomass between $5-17 \mathrm{~g} / \mathrm{m}^{2}$ during the 1970s and 1980s. tom-up control and top-down

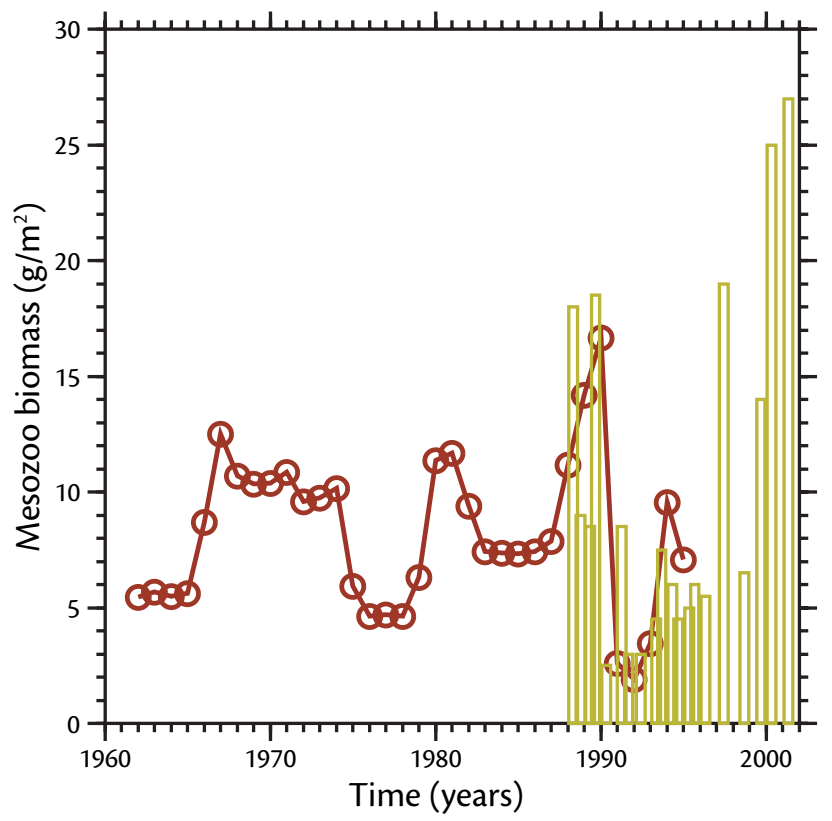

plankton biomass within the interior basin increased by an order of magnitude from 1 to $2 \mathrm{~g} / \mathrm{m}^{2}$ during the $1960 \mathrm{~s}$, to about $10 \mathrm{~g} / \mathrm{m}^{2}$ in the $1970 \mathrm{~s}$, and up to 20 $\mathrm{g} / \mathrm{m}^{2}$ at the end of the 1980s (Mikaelyan, 1997). A similar sharp increase, from 0.1 to $0.5 \mathrm{mg} / \mathrm{m}^{3}$, was also observed in the summer surface chlorophyll concentrations (Vedernikov and Demidov, 2002; Yunev et al., 2002). The variability shown in Figure 3 includes all available measurements within the deep basin during the summer and autumn months, and therefore, reflects a robust feature of the system. As expected, they were accompanied by a sharp decrease in the Secchi depth (a measure of water transparency) by more than $10 \mathrm{~m}$ (Figure 3 ).

The eutrophic Black Sea ecosystem has produced more zooplankton biomass than it used to in its pre-eutrophication phase. But, many of the dominant mesozooplankton species support- ing fish populations were replaced by smaller, less-valuable species (Kideys et al., 2000). The long-term fodder mesozooplankton data were calculated by yearly averaging all available measurements from the northeastern Black Sea (Kovalev, et al., 1988; Kideys et al., 2000) between 5 and $17 \mathrm{~g} / \mathrm{m}^{2}$ during the $1970 \mathrm{~s}$ and 1980s (Figure 4). The simultaneous effects of top-down and bottom-up controls are considered to be responsible for these fluctuations.

The 1980s were dominated by opportunistic species (e.g., Noctiluca scintillans, Acartia clausi) and gelatinous carnivores (e.g., Aurelia aurita, Pleurobrachia pileus, Mnemiopsis leidyi) (Shushkina et al., 1998; Kovalev et al., 1998; Shiganova, 1998; Mutlu, 1999; Vinogradov et al., 1999; Kideys et al., 2000). The sum of Aurelia and Pleurobrachia biomass (dominated mostly by Aurelia) increased from values of $0.2 \mathrm{~kg} / \mathrm{m}^{2}$ in the $1960 \mathrm{~s}$, to about
0.4 to $0.5 \mathrm{~kg} / \mathrm{m}^{2}$ in the $1970 \mathrm{~s}$ (Kovalev and Piontkovski, 1998), to 1.0 to $1.5 \mathrm{~kg} /$ $\mathrm{m}^{2}$ from 1978 to 1988 (Figure 5a). No appreciable contribution of Mnemiopsis was found during the latter period following its introduction into the Black Sea from 1982 to 1983. This invasive species, however, suddenly occupied the entire gelatinous stock of more than $2.5 \mathrm{~kg} / \mathrm{m}^{2}$ during 1989 , and $\sim 1.5 \mathrm{~kg} / \mathrm{m}^{2}$ during the subsequent two years (Figure 5a). The other gelatinous groups constituted only 10 percent of the stock at the time of the Mnemiopsis population explosion. The explosion coincided with a sudden decline in various fish stocks, most notably small pelagics (Figure 6). Strong predation by Mnemiopsis on eggs and the early life stages of small pelagics, and their competition with small pelagics for food (mesozooplankton) have been considered as the major causes for decline of the anchovy fishery (Kideys et al., 2000; Kideys et al., this issue). An alternate mechanism offered to explain the decline of the anchovy fishery has been recruitment failure arising from overfishing during the 1980s (Gucu, 2002; Shiganova, 1998; Daskalov, 2002).

\section{Modifications in the Vertical Biogeochemical Pump}

Transformations in plankton community structure altered the vertical biogeochemical pump by means of an apparent increase in organic matter content (Konovalov et al., 1999), enhanced bacterial production and organic matter decomposition (Vinogradov et al., 1999; Sorokin, 2002), and, subsequently, higher rates of oxygen consumption (Konovalov and Murray, 2001). More active organic matter decomposition then 
led to a higher rate of nitrogen production, and a three- to four-fold increase in nitrogen concentrations within the interior basin's chemocline. The position of the nitrogen maximum zone is also elevated upward from the density level of $\sigma_{\mathrm{t}}=\sim 15.8 \mathrm{~kg} / \mathrm{m}^{3}$ to $\sigma_{\mathrm{t}}=\sim 15.5 \mathrm{~kg} / \mathrm{m}^{3}$ (Tugrul et al., 1992). All of these changes reflect deposition of anthropogenic nitrogen throughout the basin. At the same time, the oxycline became much steeper and narrower, implying upward expansion and broadening of the oxygen-deficient suboxic layer, even though onset of the oxycline (around $\sigma_{t}=\sim 14.5$ $\mathrm{kg} / \mathrm{m}^{3}$ ) and position of the sulfide interface (around $\sigma_{\mathrm{t}}=\sim 16.2 \mathrm{~kg} / \mathrm{m}^{3}$ ) remained almost unchanged (Basturk et al., 1998). Konovalov and Murray (2001) reported thickening of the suboxic zone from 20 to $70 \mathrm{~m}$ within the interior Black Sea from 1961 to 1995 which, in terms of density, corresponded to a change from $\sigma_{\mathrm{t}}=\sim 0.3 \mathrm{~kg} / \mathrm{m}^{3}$ to $\sigma_{\mathrm{t}}=0.7 \mathrm{~kg} / \mathrm{m}^{3}$ (Figure $7)$. These changes occurred mainly during the 1980s at the time of most efficient organic matter production (Figure 3). Active organic matter decomposition continues to take place via consumption of nitrogen further below within the suboxic zone. The nitracline below the maximum nitrate concentration zone then became gradually steeper, as nitrate concentration declined towards the anoxic interface located roughly at $\sigma_{\mathrm{t}}=$ $\sim 16.2 \mathrm{~kg} / \mathrm{m}^{3}$ level. Further below, within the anoxic layer, once nitrate was depleted entirely, organic matter decomposition proceeded via sulfide reduction. The increase in the rate of this process is inferred by the steep rise in the yearly and basin-averaged hydrogen sulfide concentrations at the $\sigma_{\mathrm{t}}=\sim 16.4 \mathrm{~kg} / \mathrm{m}^{3}$ surface
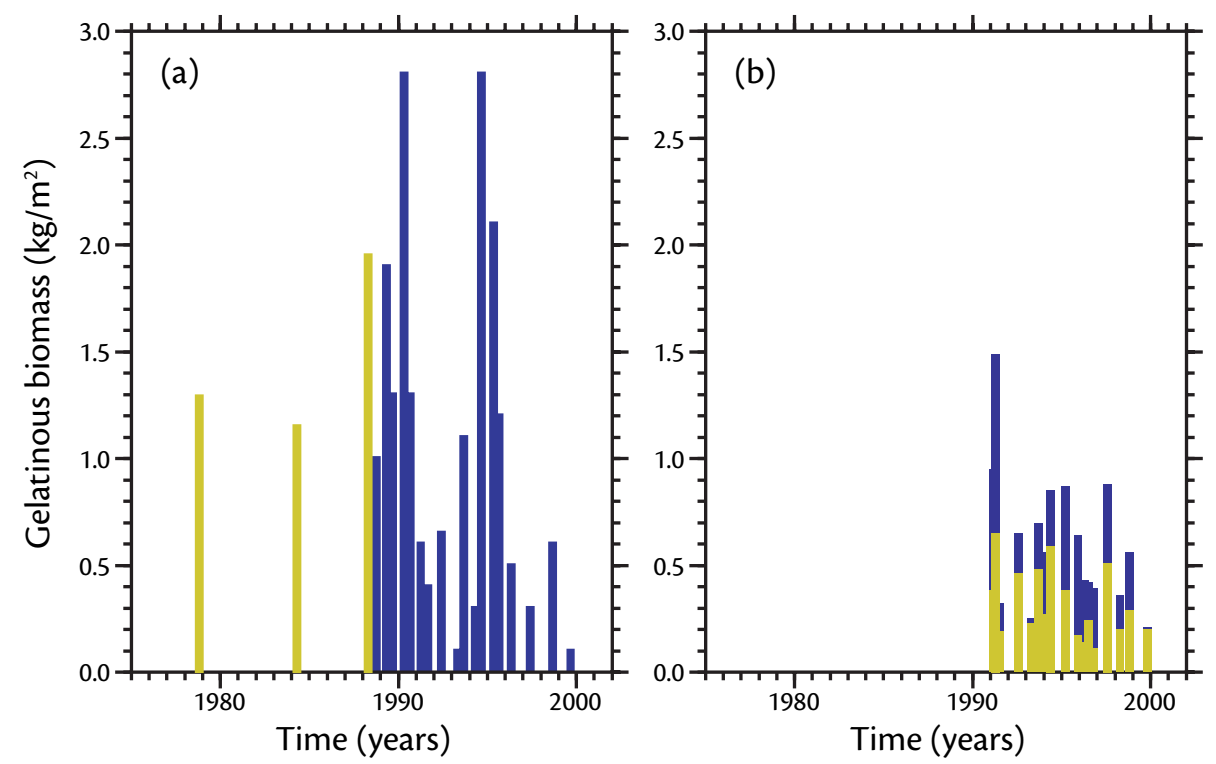

Figure 5. Temporal variations of gelatinous carnivore biomass from the measurements (a) in the northeastern sector (Shiganova et al., 2003), (b) southern sector of the Black Sea (Kideys, 2002). Yellow indicates the sum of Aurelia and Pleurobrachia biomass, and blue indicates Mnemiopsis biomass. Note that the northeastern data shown in (a) does not include the sum of Aurelia and Pleurobrachia biomass during the 1990s. The differences in the values of gelatinous carnivore biomass in the northeastern and southern sectors of the sea are due to different measurement methodologies, but both data sets show qualitatively similar annual variations. Note on the left hand side plot that jellyfish Aurelia biomass has already exceeded $1.0 \mathrm{~kg} / \mathrm{m}^{2}$ in the early $1980 \mathrm{~s}$, and replaced by population explosion of Mnemiopsis leidyi up to $\sim 3.0 \mathrm{~kg} / \mathrm{m}^{2}$ at the end of $1980 \mathrm{~s}$.

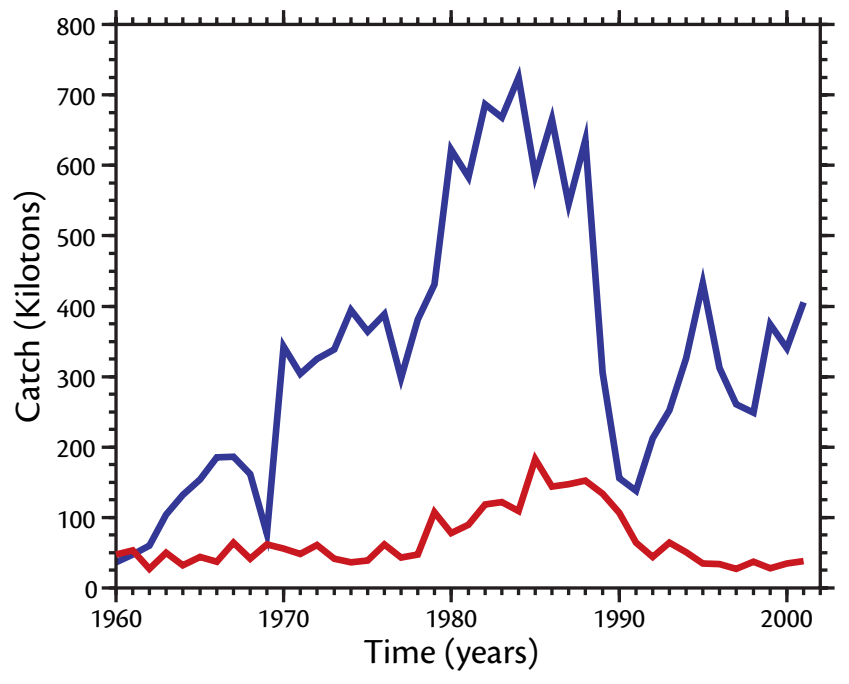

Figure 6. Long-term changes in the Black Sea fish catches (in kilotons) of small pelagics (shown in blue) and the sum of medium and large pelagics (shown in red). The data are taken from http://www.seaaroundus.org/lme/. Depletion of medium and large pelagic stocks during the 1970 s led small pelagics to act as the dominant predators in the ecosystem with subsequent increase in their stock, which was exploited by excessive and uncontrolled fishing during the 1980s. An order of magnitude increase in phytoplankton biomass due to eutrophication seems to have a positive impact on the small and large pelagic stocks during the 1980s prior to their collapse at 1990. 


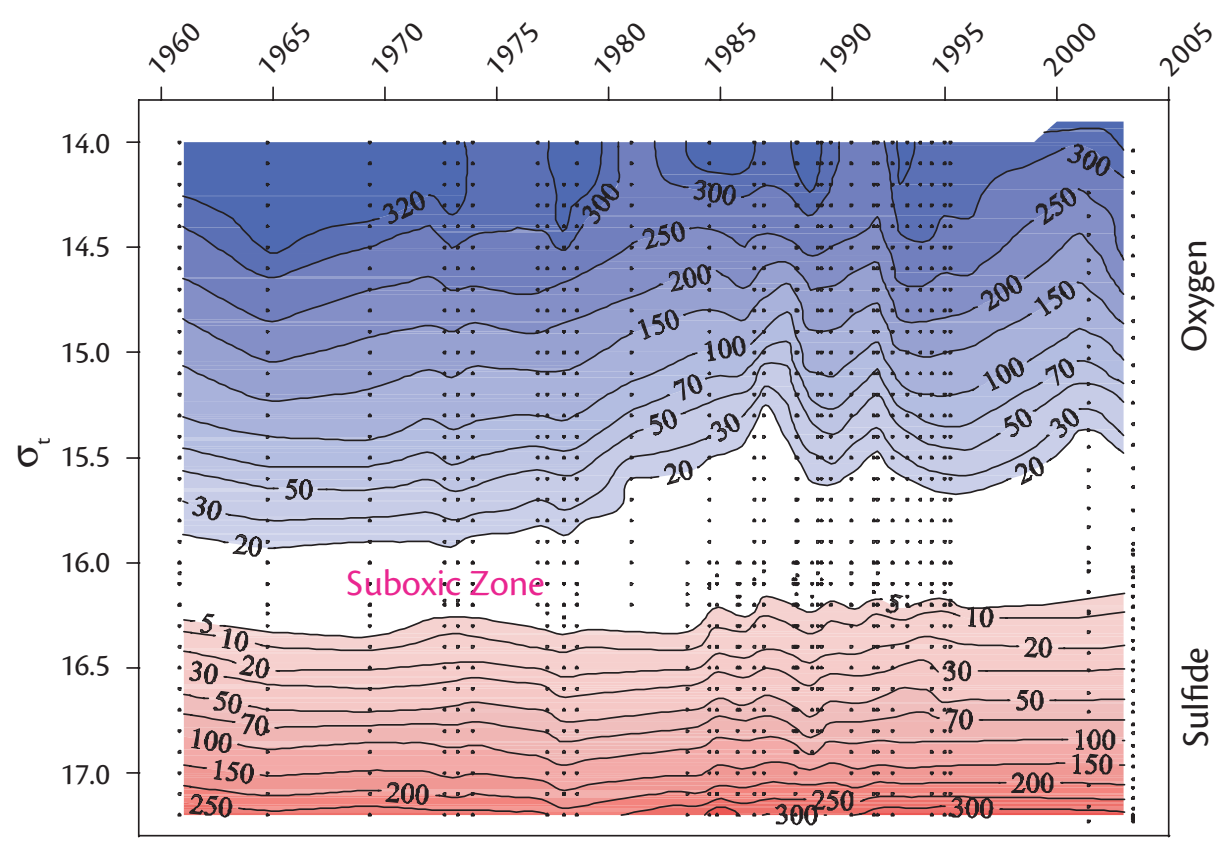

Figure 7. Temporal distribution of dissolved oxygen and hydrogen sulfide concentrations $(\mu \mathrm{M})$ versus $\sigma_{\mathrm{t}}\left(\mathrm{kg} / \mathrm{m}^{3}\right)$ used as the vertical coordinate. The layer between $20 \mu \mathrm{M}$ oxygen and $5 \mu \mathrm{M}$ hydrogen sulfide concentrations includes variations of the suboxic layer in the Black Sea (after Konovalov et al., this issue). Enhanced biological production in the surface layer associated with the eutrophication led to more active oxygen consumption at deeper levels during the remineralization process. Consequently, the upper boundary of the Suboxic Layer (SOL), defined by dissolved oxygen concentrations less than $10 \mu \mathrm{M}$, has been elevated upwards. The SOL having a thickness of $\sim 20 \mathrm{~m}$ prior to the eutrophication phase of the ecosystem was broadened to 40 to $50 \mathrm{~m}$ during the intense eutrophication phase of the 1980s. The position of the anoxic interface characterized by the depletion of hydrogen sulfide concentrations has also changed to some extent during the eutrophication phase.

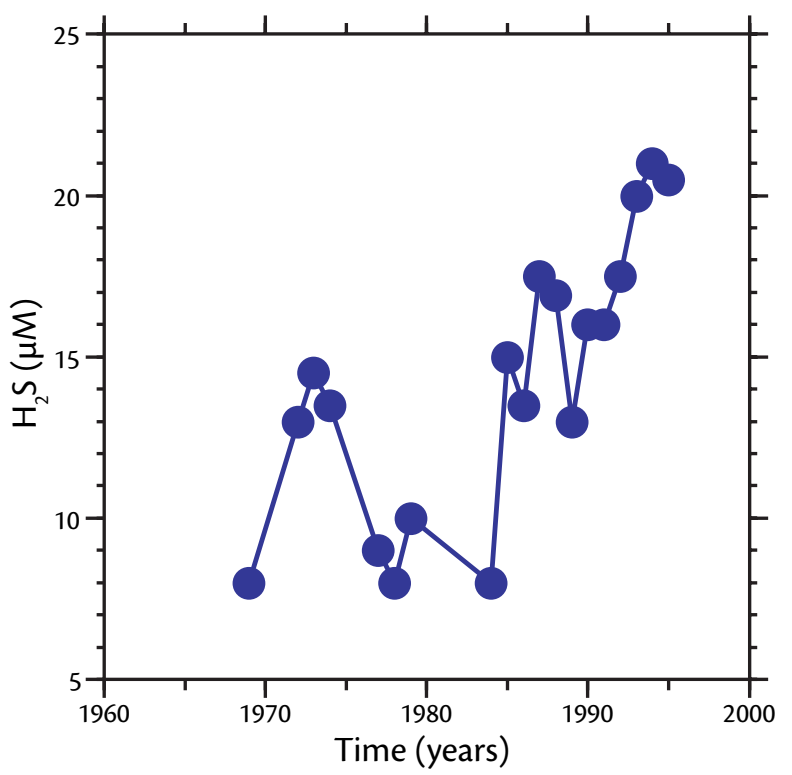

from about $10 \mu \mathrm{M}$ during the 1970 s to $20 \mu \mathrm{M}$ at the end of the 1980s and the early 1990s (Figure 8).

\section{IMPACTS OF OVERFISHING AND POPULATION OUTBURST OF GELATINOUS AND OPPORTUNISTIC SPECIES IN THE 1980s AND 1990s}

One of the most important features of the eutrophic Black Sea was diversion of the classical phytoplankton-zooplankton-fish food chain to an alternative pathway of phytoplankton-zooplanktonopportunistic species-gelatinous carnivores during the 1980s. Eutrophication alone was not sufficient to drive all the transformations in the food chain. It was complemented by the heavy, unregulated fishing ferociously continued since the early phase of the eutrophication (i.e., the 1970s).

Overfishing caused the sharp reduction and/or disappearance of medium and large pelagic fish catches (Figure 6). Removal of large fish from the system ("the fishing down" phenomenon) made the smaller and less-valuable planktivorous fishes (mainly anchovy and sprat) the dominant predators in the ecosystem. This change doubled the exploited stocks of anchovy and sprat (Prodanov et al., 1997), and subsequently their total catch at the end of the 1970s (Figure 6). As a result, a new and different type of top-down cascade started operating on the lower levels of the food web, resulting in a two-fold decline in mesozooplankton biomass and a comparable increase in phytoplankton biomass during the 1970s (Daskalov 2002, Gucu 2002). The increase encountered in total phytoplankton biomass (Figure 3), therefore, 
was not a result of eutrophication alone, but a process that also included overfishing (i.e., top-down effect).

Once the small pelagics became the main target of industrial fishing, their catches started decreasing and were gradually shifted towards newly recruited, small-sized fish groups during the 1980s. The catches finally exceeded a sustainable level in 1987 and 1988 (Shiganova, 1998; Gucu, 2002; Daskalov, 2002), and collapsed in 1989 and 1990 (Figure 6). The niche vacated by these fish groups was gradually replaced by gelatinous zooplankton (the jellyfish $A u$ relia aurita, in particular) and other opportunistic species (e.g., Noctiluca scintillans). The increase in Aurelia biomass in the 1970s might have been associated with overfishing and removal of mackerel, which was a main predator of $\mathrm{Au}$ relia in Black Sea (Arai, 2001). Because of their competitive advantage for food as compared to small pelagics, and their predation on eggs and larvae of small pelagics, the total gelatinous biomass, mostly of the jellyfish Aurelia aurita, reached $1.5 \mathrm{~kg} / \mathrm{m}^{2}$ during the mid-1980s, and finally attained the peak value of about $2.5 \mathrm{~kg} / \mathrm{m}^{2}$ in 1989 when the population of the ctenophore Mnemiopsis leidyi exploded (Figure 5a). Relaxation of the fishing pressure during the second half of the 1980s may be responsible for a gradual increase in the mesozooplankton biomass up to its maximum value of $15 \mathrm{~g} / \mathrm{m}^{2}$ in 1990 (Figure 4), when the small pelagic fish stock collapsed (Figure 6) and the Mnemiopsis population exploded (Figure 5a).

The years 1992 to 1993 were very special for the Black Sea ecosystem. The Mnemiopsis biomass decreased sharply to around $0.5 \mathrm{~kg} / \mathrm{m}^{2}$ immediately after their dramatic outbreak (Figure 5a). The mesozooplankton biomass also dropped from $17 \mathrm{~g} / \mathrm{m}^{2}$ during 1990 to around 2 to $4 \mathrm{~g} / \mathrm{m}^{2}$ from 1991 to 1993 (Figure 4). They were accompanied with lowest level of fish stocks (Figure 6) and the highest level of phytoplankton biomass (Figure 3 ) since the 1960s. The reversed trend observed within the next two years was characterized by increases in the biomass of mesozooplankton and Mnemiopsis, and in the fish catch, and by a decrease in phytoplankton biomass. Mnemiopsis biomass immediately attained its previous peak level observed at the end of the 1980s. The plankton and fish stocks continued to oscillate during the second half of the 1990s. Mnemiopsis and fish stocks tended to decrease up to 1998 , and mesozooplankton biomass maintained more or less a steady level around 5 to $7 \mathrm{~g} / \mathrm{m}^{2}$, except for the observed peak in spring 1997 following a relatively strong winter season. Phytoplankton biomass continued to decrease during this phase. Toward the end of the decade, the Black Sea ecosystem had been influenced by a new invader, the ctenophore Beroe ovata, a predator of Mnemiopsis.

We note that the gelatinous biomass data may require some calibration because of the lack of standard measurement techniques among different research groups (Niermann et al., 1995). Two different data sets, shown in Figures $5 \mathrm{a}$ and $5 \mathrm{~b}$, exhibit large differences in the biomass values, even though they exhibited similar temporal variations. The data shown in Figure 5 a were from the northeastern Black Sea (Shiganova et al., 2001, 2003) and differed five to six fold from those obtained within the southern
Black Sea (Figure 5b) (Niermann et al., 1995; Mutlu, 2001).

\section{IMPACT OF CTENOPHORE BEROE OVATA IN THE LATE 1990s}

Beroe ovata has been introduced into the Black Sea with ballast waters in 1998, acclimated quickly and easily to the Black Sea conditions, and spread a year later over the northwestern, northeastern, and southern Black Sea. The systematic observations carried out within the northeastern Black Sea from 1999 to 2001 (Shiganova et al., 2003) indicated a complex prey-predator interaction between Mnemiopsis and Beroe. The biomass of Mnemiopsis, up to $2.0 \mathrm{~kg} / \mathrm{m}^{2}$ in August, was found to drop by an order of magnitude within a month following active reproduction of Beroe from September to October. Reproduction rates of Beroe then decreased as the Mnemiopsis stock was gradually depleted in the autumn months. Only a small fraction of the Beroe population remained alive until the next burst of Mnemiopsis. Thus, although high values of Mnemiopsis biomass are still occasionally observed, its impact on the ecosystem has been limited to 1 to 2 months during the late summer, as compared to 8 to 9 months from early spring to late autumn prior to the settlement of Beroe in the Black Sea. In contrast, the biomass of Aurelia and Pleurobrachia, which were not consumed by Beroe, remained at its pre-1999 level of about 0.3 to $0.4 \mathrm{~kg} / \mathrm{m}^{2}$ (Shiganova, et al., 2001).

Predation of Mnemiopsis by Beroe was immediately reflected by a two- to three-fold increase in mesozooplankton biomass (Figure 4), ichthyoplankton biomass, and fish stocks (Shiganova et al., 
2003). The latter emerged in the form of a gradual increase of the fish catch after 1998 (Figure 6).

\section{CONCLUSIONS}

The present study puts together various data sets on the ecological transformation of the Black Sea during the last three decades. We specifically focused our attention on the functioning of the deep interior basin ecosystem, but most of the results and findings are readily applicable to the northwestern shelf ecosystem. The anthropogenic forcing described here includes (1) bottom-up control of the ecosystem by excessive nutrient loading from rivers during the 1970s, which lead to eventual deposition of excess nutrients within the bottom water layer in shallow coastal regions, and the deep interior basin's chemocline layer to follow an active organic matter remineralization cycle; and (2) top-down control of the ecosystem by the overfishing of pelagic fishes and a population outburst of gelatinous carnivores, which were both most prevalent during the 1980s. These simultaneous controls have exerted decadalscale variations, which have consistently emerged in different data sets that show order-of-magnitude changes.

Our analysis suggests that eutrophication, developed as a consequence of the over-fertilization of the sea by nutrients, started deteriorating the ecosystem from the lowest trophic level during the 1970s; its impact then propagated towards higher trophic levels. Plankton community structure was altered in terms of species succession, intensity, frequency, and spatial extension of algal blooms, as well as a shift towards both smaller and less-valuable fodder mesozooplankton groups and opportunistic and gelatinous species. Overfishing then introduced a further shock into the ecosystem already perturbed by the eutrophication. By depletion of large pelagics during the early 1970s, small pelagic fishes started acting as the main predator in the system. They exerted stronger grazing pressure on mesozooplankton, and thus favored more-enhanced phytoplankton production. But, the main effect of overfishing was felt later when the small pelagic stocks were overfished during the 1980s. Their niche was filled by gelatinous and opportunistic species, which gradually took control of the entire ecosystem toward the end of the 1980s.

The plankton structure tended to have rather strong oscillations in the 1990s, as indicated by a sharp drop in Mnemiopsis biomass and fish catch to their minimum values in 1992 and 1993, increases to maximum in 1995, and then decreases up to 1998 . Starting by 1999 , the ctenophore Beroe ovata very effectively consumed Mnemiopsis, and helping the ecosystem to recover. So far, except for the contribution of Beroe, no convincing explanation has been given for the causes of the fluctuations that occurred in the 1980s. Eutrophication and overfishing did not seem to strongly influence the ecosystem, especially during the second half of the 1990s. The next article (see Oguz, this issue) elucidates the critical role played by climate during the 1980s and 1990s.

\section{ACKNOWLEDGEMENTS}

We thank M. Barange, G. Daskalov and

U. Niermann for comments on the early versions of the paper, and E. Mutlu, and A. Kideys for stimulating discussion. We appreciate the constructive remarks and suggestions made by the reviewers J. Purcell, S. Konovalov, and E. Stanev. This work is a contribution of the Black Sea ARENA project (EVK3-CT-200280011) and EUR-OCEANS project (the European Commission contract number 511106). .

\section{REFERENCES}

Arai, M.N. 2001. Pelagic coelenterates and eutrophication: a review. Hydrobiologia 451:69-87.

Basturk, O., S. Tugrul, S.K. Konovalov, and I. Salihoglu. 1997: Variations in the vertical structure of water chemistry within the three hydrodynamically different regions of the Black Sea. Pp. 183-196 in Sensitivity to Change: Black Sea, Baltic Sea and North Sea, E. Ozsoy and A.S. Mikaelyan, eds. NATO ASI Series 2: Environmental Security 27. Kluwer Academic Publishers, Dordrecht, The Netherlands.

Basturk, O., S. Tugrul, S. Konovalov, and I. Salihoglu. 1998. Effects of circulation on the spatial distributions of principle chemical properties and unexpected short- and long-term changes in the Black Sea. Pp. 39-54 in Ecosystem Modeling as a Management Tool for the Black Sea, L.I. Ivanov and T. Oguz, eds. NATO ASI Series 2: Environment 47. Kluwer Academic Publishers, The Netherlands.

Bilio, M. and U. Niermann. 2004. Is the comb jelly really to blame for it all? Mnemiopsis leidyi and the ecological concerns about the Caspian Sea. Marine Ecology Progress Series 269:173-183.

Bodeanu, N. 1993. Microbial blooms in the Romanian area of the Black Sea and contemporary eutrophication conditions. Pp. 203-209 Toxic Phytoplankton Blooms in the Sea, T.J. Smayda and Y. Shimizu, eds. Elsevier, Amsterdam.

Cociasu, A. and L. Popa. 2002. Significant changes in Danube nutrient loads and their impact on the Romanian Black Sea shelf. Unpublished manuscript.

Cociasu, A., L. Dorogan, C. Humborg, and L. Popa. 1996. Long-term ecological changes in the Romanian coastal waters of the Black Sea. Marine Pollution Bulletin 32:32-38.

Daskalov, G.M. 2002. Overfishing drives a trophic cascade in the Black Sea. Marine Ecology Progress Series 225:53-63.

Gucu, A.C. 2002. Can overfishing be responsible for the successful establishment of Mnemiopsis leidyi in the Black Sea? Estuarine, Coastal and Shelf Science 54:439-451.

Gucu, A.C. and T. Oguz. 1998. Modeling trophic interrelationships in the Black Sea. Pp. 359-371 in Ecosystem Modeling as a Management Tool for 
the Black Sea, L. Ivanov and T. Oguz, eds. NATO ASI Series 2: Environment 47. Kluwer Academic Publishers, Dordrecht, The Netherlands.

Humborg, C., V. Ittekkot, A. Cociasu, and B. Bodungen. 1997. Effect of Danube River dam on Black Sea biogeochemistry and ecosystem structure. Nature 386:385-388.

Kideys, A.E. 2002. Fall and rise of the Black Sea ecosystem. Science 297:1482-1484.

Kideys, A.E. and Z. Romanova. 2001. Distribution of gelatinous macrozooplankton in the southern Black Sea during 1996-1999. Marine Biology 139:535-547.

Kideys, A.E., A.V. Kovalev, G. Shulman, A. Gordina, and F. Bingel. 2000. A review of zooplankton investigations of the Black Sea over the last decade. Journal of Marine Systems 24:355-371.

Konovalov, S.K., V.N. Eremeev, A.M. Suvorov, A.K. Khaliulin, E.A. Godin. 1999. Climatic and anthropogenic variations in the sulfide distribution in the Black Sea. Aquatic Geochemistry 5:13-27.

Konovalov, S.K. and J.W. Murray. 2001. Variations in the chemistry of the Black Sea on a time scale of decades (1960-1995). Journal of Marine Systems 31:217-243.

Kovalev, A.V and S.A. Piontkovski. 1998. Interannual changes in the biomass of the Black Sea gelatinous zooplankton. Journal of Plankton Research 20:1377-1385.

Kovalev, A.V., U. Neirman, V.V. Melnikov, V. Belokopytov, Z. Uysal, A.E. Kideys, M. Unsal, and D. Altukov. 1998. Long-term changes in the Black Sea zooplankton: The role of natural and anthropogenic factors. Pp. 221-234 in Ecosystem Modeling as a Management Tool for the Black $\mathrm{Sea}$, L. Ivanov and T. Oguz, eds. NATO ASI Series 2: Environment 47. Kluwer Academic Publishers, Dordrecht, The Netherlands.

Mankovsky, V.I., V.L. Vladimirov, M.V. Solovev, and S. Besiktepe. 1998. Optical properties of the Black Sea: Results of the CoMSBlack and TU-Black Sea Programs. Pp. 145-162 in Ecosystem Modeling as a Management Tool for the Black Sea, L. Ivanov and T. Oguz, eds. NATO ASI Series 2: Environment 47. Kluwer Academic Publishers, Dordrecht, The Netherlands.

Mee, L.D. 1992. The Black Sea in crisis: A need for concerted international action. Ambio 21:278-286.

Mikaelyan, A.S. 1997. Long-term variability of phytoplankton communities in open Black Sea in relation to environmental changes. Pp. 105-116 in Sensitivity to Change: Black Sea, Baltic Sea and North Sea, E. Ozsoy, and A. Mikaelyan, eds. NATO ASI Series 2: Environment 27. Kluwer Academic Publishers, Dordrecht, The Netherlands.

Moncheva, S. and A. Krastev. 1997. Some aspects of phytoplankton long-term alterations off Bulgarian Black Sea Shelf. Pp. 79-94 in Sensitivity to Change: Black Sea, Baltic Sea and North Sea, E. Ozsoy, and A. Mikaelyan, eds. NATO ASI Series 2: Environment 27. Kluwer Academic Publishers, Dordrecht, The Netherlands.

Mutlu, E. 1999. Distribution and abundance of ctenophores and their zooplankton food in the Black Sea. II: Mnemiopsis leidyi. Marine Biology 135:603-613.

Mutlu, E. 2001. Distribution of gelatinous macrozooplankton and ecosystem change in the Black Sea. Pp. 75-80 in Gelatinous Zooplankton Outbreaks: Theory and Practice. CIESM Workshop Series 14. International Commission for the Scientific Exploration of the Mediterranean Sea (CIESM), de Suisse, Monaco.

Niermann, U., A.E. Kideys, S. Besiktepe, B. Nicolae, A. Goubanova, V. Khoroshilov, A. Mikaelyan, S. Moncheva, E. Mutlu, N. Nezlin, A. Petranu, L. Senichkina, and T. Shiganova. 1995. An Assessment of Recent Phyto- and Zooplankton Investigations in the Black Sea and Planning for Future. Report on the meeting of marine biologist in Erdemli, Turkey, February 20-March 3, 1995. Institute of Marine Sciences, Middle East Technical University, Erdemli, Turkey, 100 pp.

Oguz, T, H.W. Ducklow, and P. Malanotte-Rizzoli. 2000. Modeling distinct vertical biogeochemical structure of the Black Sea: Dynamical coupling of the oxic, suboxic and anoxic layers. Global Biogeochemical Cycles 14:1331-1352.

Popa, L. 1995. Observations sur le phosphore dissous dans les eaux du littoral Rouman de la Mer Noire. Cercetari Marine 28:19-28.

Prodanov, K, K. Mikhaylov, G. Daskalov, K. Maxim, E. Ozdamar, V. Shlyakhov, A. Chashcin, and A. Arkhipov. 1997. Environmental management of fish resources in the Black Sea and their rational exploitation. General Fisheries Council of the Mediterranean Studies and Reviews 68:1-178.

Richardson, K. and B.B. Jorgensen. 1996. Eutrophication: definition, history and effects. Pp. 1-19 in Eutrophication in Coastal Marine Ecosystems, B.B. Jørgensen and K. Richardson, eds. Coastal and Estuarine Studies 52. American Geophysical Union, Washington, D.C.

Shiganova, T.A. 1998. Invasion of the Black Sea by the ctenophore Mnemiopsis leidyi and recent changes in pelagic community structure. Fisheries Oceanography 7:305-310.

Shiganova, T.A., Yu. V. Bulgakova, S.P. Volovik, Z.A. Mirzoyan, and S.I. Dudkin. 2001. The new invader Beroe ovata Mayer 1912 and its effect on the ecosystem in the northeastern Black Sea. Hydrobiologia 451:187-197.

Shiganova, T.A., E.I. Musaeva, Yu. V. Bulgakova, Z.A. Mirzoyan, and M.L. Martynyuk. 2003. Invaders Ctenophores Mnemiopsis leidyi (A.
Agassiz) and Beror ovata Mayer 1912, and their influence on the pelagic ecosystem of northeastern Black Sea. Oceanology (Engl. Trans.), 30(2):180-190.

Shushkina, E.A., M.E. Vinogradov, L.P. Lebedeva, T. Oguz, N.P. Nezlin, V. Yu. Dyakonov, and L.L. Anokhina. 1998. Studies of structural parameters of planktonic communities of the open part of the Black Sea relevant to ecosystem modeling. Pp. 311-326 in Ecosystem Modeling as a Management Tool for the Black Sea, L.I. Ivanov and T. Oguz, eds. NATO ASI Series 2: Environment 47. Kluwer Academic Publishers, The Netherlands.

Sorokin, Y.I. 2002. The Black Sea Ecology and Oceanography. Backhuys Publishers, Leiden, 875 pp.

Tugrul, S., O. Basturk, C. Saydam, and A. Yilmaz. 1992. The use of water density values as a label of chemical depth in the Black Sea. Nature 359:137-139.

Vedernikov, V.I. and A.B. Demidov. 2002. Longterm and seasonal variability of chlorophyll and primary production in the eastern regions of the Black Sea. Pp. 212-234 in Multidisciplinary Investigations of the Northeast Part of the Black Sea, A.G. Zatsepin and M.V. Flint, eds. Moscow, Nauka.

Vinogradov, M.E. 1990. Investigation of the pelagic ecosystem of the Black Sea ( $44^{\text {th }}$ cruise of the R/V Dimitriy Mendeleyev, July 4-September 17, 1989. Oceanology 30(2):254-256.

Yunev, O.A, V.I. Vedernikov, O. Basturk, A. Yilmaz, A.E. Kideys, S. Moncheva, and S. Konovalov. 2002. Long-term variations of surface chlorophyll-a and primary production in the open Black Sea. Marine Ecology Progress Series 230:11-28.

Zaitsev, Yu. and V. Mamaev. 1997. Marine Biological Diversity in the Black Sea: A Study of Change and Decline. GEF Black Sea Environmental Programme. United Nations Publications, New York, 208 pp. 